\title{
Oral lesions among HIV seropositive individuals in an era of generic HAART: markers of HAART efficacy?
}

\author{
Janani Vasudevan ${ }^{1}$, Vaishnavi Sivasankar ${ }^{1 *}$, Umadevi K Rao ${ }^{1}$, Nagalingeswaran Kumarasamy², Kannan Ranganathan ${ }^{1}$ \\ From First International Science Symposium on HIV and Infectious Diseases (HIV SCIENCE 2012) \\ Chennai, India. 20-22 January 2012
}

\section{Background}

Oral lesions have been established as a clinical feature of human immunodeficiency virus (HIV) seropositivity. Treatment with Highly Active Antiretroviral Therapy (HAART) has changed the course of infections with HIV. This study correlates the oral lesion prevalence in HAART and non-HAART groups in a cohort of HIV seropositive patients in Southern India.

\section{Methods}

The study group consisted of 3485 HIV seropositive patients who reported to the dental clinic of YRG CARE, Chennai, India. Oral lesions were diagnosed clinically based on EC Clearinghouse criteria and the data was analyzed using SPSS software.

\section{Results}

In the study population, $92.3 \%$ of individuals had acquired the infection through heterosexual contact. The mean age of infected males and females was $35 \pm 8$ and $30 \pm 8$ years respectively and the mean CD4 count in males and females was $385.53 \pm 226.76$ and 284.36 \pm 278.28 cells $/ \mu \mathrm{L}$ respectively $(\mathrm{p}<0.05)$. Patients having CD4 count $<200(n=908)$ had more number of oral lesions than patients with CD4 count $>200(\mathrm{p}<0.01)$. Patients on HAART $(\mathrm{n}=1042)$ had a lesser number of lesion than patients not on HAART $(\mathrm{p}<0.01)$. Of the lesions, candidiasis was predominantly seen in the nonHAART group (19.7\%) as compared to the HAART group (11.7\%). Patients who were not on HAART showed a higher prevalence of pseudomembranous

\footnotetext{
*Correspondence: vaishnavisiv@gmail.com

'Department of Oral and Maxillofacial Pathology, Ragas Dental College, Chennai, India

Full list of author information is available at the end of the article
}

candidiasis $(12.8 \%$ vs. $7.9 \%, \mathrm{p}<0.01)$ and angular cheilitis (6.0\% vs. $3.7 \%, \mathrm{p}<0.01)$.

\section{Conclusion}

Patients on Highly Active Antiretroviral Therapy (HAART) demonstrate fewer oral lesions, which can serve as markers of treatment efficacy. Long term follow-up studies are necessary to validate these results.

\section{Author details}

'Department of Oral and Maxillofacial Pathology, Ragas Dental College,

Chennai, India. ${ }^{2}$ YRG Centre for AIDS Research and Education, Chennai, India.

Published: 4 May 2012

doi:10.1186/1471-2334-12-S1-P39

Cite this article as: Vasudevan et al: Oral lesions among HIV

seropositive individuals in an era of generic HAART: markers of HAART efficacy? BMC Infectious Diseases 2012 12(Suppl 1):P39.

Submit your next manuscript to BioMed Central and take full advantage of:

- Convenient online submission

- Thorough peer review

- No space constraints or color figure charges

- Immediate publication on acceptance

- Inclusion in PubMed, CAS, Scopus and Google Scholar

- Research which is freely available for redistribution

Submit your manuscript at www.biomedcentral.com/submit

\section{() Biomed Central}

\section{Ciomed Central}

